\title{
Long sequence of Quaternary Rocks in the Heidelberg Basin Depocentre
}

\author{
Dietrich Ellwanger, Gerald Gabriel, Theo Simon, Ulrike Wielandt-Schuster, \\ Reinhard O. Greiling, Eva-Marie Hagedorn, Jürgen Hahne \& Jürgen Heinz *)
}

\begin{abstract}
A description and classification of the successions of the new scientific core drillings at Heidelberg is presented. Since 2002 drilling and research activities were ongoing in the Heidelberg Basin (HDB), as a mid-continental sedimentary archive within the Upper Rhine Graben (URG), Germany. The HDB is supposed to host one of the longest continuous successions of Quaternary sediments in Europe, due to continuous subsidence of the basin and sediment input from various sources. The HDB is about half-way between the Alpine source area of the Rhine and the North Sea. Here the Quaternary input is least affected by discontinuities due to climate events as alpine glacier meltdown events or periods of low sea level. Reversely, the low influence of climate leads to a larger tectonic control. The sedimentary succession of more than $500 \mathrm{~m}$ is considered as primarily controlled by tectonics, but with incorporated climate signals. For classification purposes, sediment provenance, lithofacies-associations, and the ratio of accommodation space and sediment input are used. Some biostratigraphic markers are also available. We suggest a sedimentary scenario where the overall fluvial environment is twice interrupted by lacustrine intervals. The accommodation space varies too: in one period it expands even beyond the eastern boundary fault of the HDB.
\end{abstract}

\section{[Mächtige Abfolge quartärer Sedimente im Depozentrum des Heidelberger Beckens]}

Kurzfassung: Die neue Forschungs-Kernbohrung aus Heidelberg wird beschrieben und gegliedert. Die Forschungs- und Bohraktivitäten im Heidelberger Becken (HDB) begannen im Jahr 2002; sie erschließen ein kontinentales Sedimentarchiv im Oberrheingraben (URG). Im HDB wird eine der längsten Sedimentabfolgen quartärer Sedimente in Europa erwartet, dank kontinuierlicher Subsidenz des Beckens in Verbindung mit kontinuierlichem Input von Sedimenten unterschiedlicher Herkunft. Das HDB befindet sich auf halber Strecke zwischen dem alpinen Einzugsgebiet des Rheins und seiner Mündung in die Nordsee. Eine kontinuierliche Sedimentation ist hier eher möglich als am Alpenrand mit seinen Schmelzwasser-Erosionsereignissen oder an der Küste mit ihren Meeresspiegelschwankungen. Dieser eher geringe Einfluss des Klimas hat zur Folge, dass die Tektonik eine umso größere Rolle bei der Steuerung der Sedimentation spielt. Die über $500 \mathrm{~m}$ mächtige quartäre Abfolge ist daher in erster Linie durch Tektonik kontrolliert, wobei Klimasignale ebenfalls

\footnotetext{
*Addresses of authors: D. Ellwanger, Regierungspräsidium Freiburg, Abteilung 9 (Landesamt für Geologie, Rohstoffe und Bergbau), Albertstraße 5, 79104 Freiburg i. Br., Germany. E-Mail: dietrich.ellwanger@, rpf.bwl.de; G. Gabriel, Leibniz Institute for Applied Geophysics, Stilleweg 2, 30655 Hannover, Germany. E-Mail: gerald.gabriel@liag-hannover.de; T. Simon, Regierungspräsidium Freiburg, Abteilung 9 (Landesamt für Geologie, Rohstoffe und Bergbau), Albertstraße 5, 79104 Freiburg i. Br., Germany. E-Mail: theo.simon@rpf.bwl.de; U. Wielandt-Schuster, Regierungspräsidium Freiburg, Abteilung 9 (Landesamt für Geologie, Rohstoffe und Bergbau), Albertstraße 5, 79104 Freiburg i. Br., Germany. E-Mail: ulrike.wielandtschuster@rpf.bwl.de; R. Greiling, Geologisches Institut - Strukturgeologie und Tektonophysik, Universität Karlsruhe (TH), Hertzstr. 16, 76187 Karlsruhe, Germany. E-Mail: er8@agk.uka.de, E.-M. Hagedorn, Leineweberstr. 9, 51381 Leverkusen, Germany. E-Mail: eva.hagedorn@gmx.de; J. Hahne, Tiefental 3, 37586 Dassel; Germany. E-Mail: juergenhahne@gmx.de; J. Heinz, Hydroisotop GmbH, Karl-Friedrich-Str. 19, 79312 Emmendingen; Germany. E-Mail: bw@hydroisotop.de
} 
erkannt werden können. Die hier vorgestellte Gliederung der Abfolge beruht auf Provenienz, Lithofazies und wechselnden Verhältnissen von Akkomodationsraum und Sedimentinput (a/s-ratio). Dazu kommen biostratigraphische Zeitmarken. Im skizzierten Sedimentations-Szenario dominieren fluviale Verhältnisse; dazwischen zwei lakustrine Abschnitte. Letztere sind verknüpft mit zunehmendem Akkomodationsraum, der in mindestens einer Zeitscheibe über die Grabenrandstörung hinweg sich bis in die Täler des Odenwalds erstreckt.

Keywords: Upper Rhine Graben, Heidelberg Basin, research borehole, lithofacies, sediment provenance, sequence stratigraphy, lithostratigraphy, biostratigraphy, differential uplift, subsidence.

\section{Introduction}

This paper summarises first results and impressions of the newly cored research borehole at Heidelberg. It is located at the depocentre of the „Heidelberg Basin“ (HDB), close to the eastern margin of the northern Upper Rhine Graben (URG). The probably largest and most complete Quaternary sediment succession along the Rhine has been exhibited, amounting to $>500 \mathrm{~m}$. It proved to be a fairly continuous continental archive of the Quaternary in superposition and quite good resolution.

The sediments are strongly influenced by the input of the river Neckar, a major tributary of the Rhine which has its outlet into the URG within Heidelberg. Two other boreholes representing other parts of the HDB are the borehole of Viernheim in the geographic centre of the basin (Hoselmann 2008), and the borehole of Ludwigshafen at the western margin (WEIDENFEller \& Kärcher 2008, Rolf, Hambach \& Weidenfeller 2008; Fig. 1). Their sediments are both dominated by input of the Rhine.

All three boreholes are part of a multidisciplinary research project (The Heidelberg Basin Drilling Project; Ellwanger et al. 2005, 2007, GABRIEL et al. 2008). Its aims will be to identify the interaction of climate and tectonics as controlling mechanisms of sedimentation, describe properties and 3D architecture of the infill, and contribute to the correlation of alpine and north European Quaternary stratigraphy. This paper only contributes to the basics of this research, as is it primarily focused on the Heidelberg borehole.

\section{Regional geological context}

The northern URG contains a more or less continuous succession of Oligocene, Neogene and Quaternary sediments, which accumulated due to ongoing subsidence since Oligocene time (Dèzes, Schmid \& Ziegler 2004, Duringer 1988, Gideon, Lopes Cardozo \& Behrmann 2006, Rotstein et al. 2006, Schumacher 2002, ZIEGLER 1992). In the Quaternary, the subsidence increased towards the east, which led to a halfgraben architecture with a maximum sediment thickness at the eastern margin of the URG, i.e. the Heidelberg deep (Heidelberger Loch, location of the Heidelberg borehole, BARTZ 1974). The western part of the Graben is slightly uplifted. As a result, the HDB lowlands are bordered in the east by the Odenwald highlands and the Kraichgau depression. West of the HDB, there is a widespread foothill landscape within the URG (PETERS 2007), and the Pfälzerwald highlands at the western URG shoulder (Fig. 1).

The subsidence of the HDB is balanced by sediment input throughout the Quaternary. The primary sediment sources are the fluvial systems of Rhine and Neckar. The deposits mainly reflect this fluvial environment, but also include intervals dominated by local coarse debris input from the nearby highlands, and also some lacustrine intervals. The HDB succession is, therefore, not only an archive of the Quaternary stratigraphic evolution, but also of the varying sedimentary dynamics. 


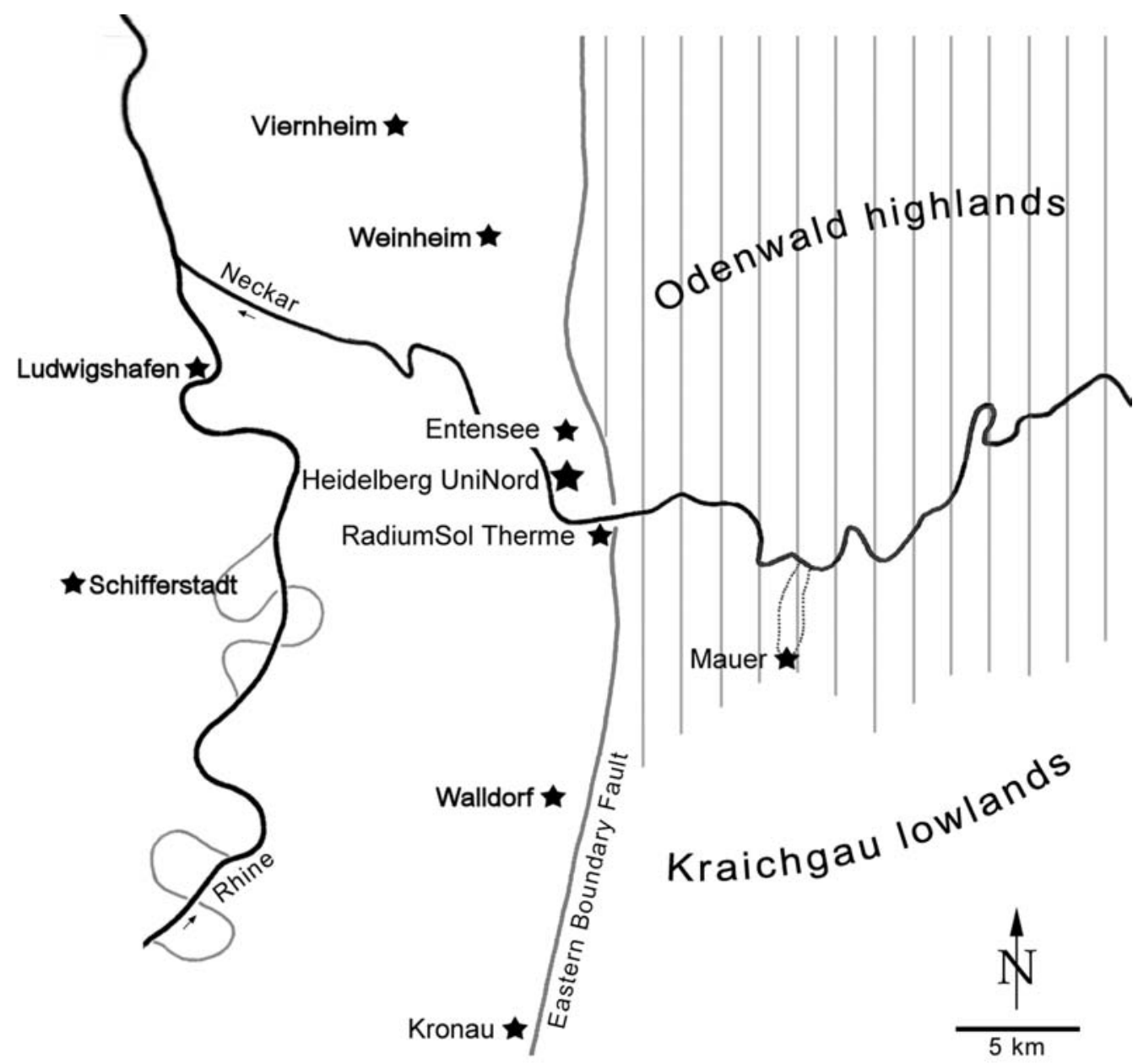

Fig. 1: Location of the UniNord boreholes in Heidelberg and other boreholes. The Eastern Boundary Fault (EBF) of the Upper Rhine Graben (URG) separates the lowland plains of the Upper Rhine from the adjacent highlands. The Heidelberg Basin (HDB) covers approximately the area between the present River Rhine and the EBF, extending some $10-15 \mathrm{~km}$ north and south of Heidelberg. The highlands east of the EBF are twoparted, the Odenwald anticline (highlands) in the north, and the Kraichgau syncline (lowlands) in the south. The Neckar valley is incised into the southern Odenwald highlands, as is the buried early Neckar valley at Mauer.

Abb. 1: Lokation der UniNord Bohrungen in Heidelberg und anderer Bohrungen. Die „östliche Hauptverwerfung" (EBF) des Oberrheingrabens (URG) trennt die Oberrheinebene von den angrenzenden Mittelgebirgen. Das Heidelberger Becken (HDB) erstreckt sich zwischen dem heutigen Rheinlauf und der EBF, sowie, ausgehend von Heidelberg, jeweils $10-15 \mathrm{~km}$ nach Norden und Süden. Die Mittelgebirge östlich der EBF sind zweigeteilt, im Norden die Odenwald-Antikline (als Mittelgebirge) und im Süden die Kraichgau-Synkline (als Tiefland). Das Neckartal ist in den südlichen Odenwald eingeschnitten, wie auch das verlassene Neckartal bei Mauer mit seiner Talverschüttung. 


\section{Definitions and methods}

\subsection{Definition of ,Quaternary“" in the Upper Rhine Graben (URG)}

Some popular stratigraphic schemes of the URG are difficult for stratigraphers to apply, as chronostratigraphic terms are used to describe lithostratigraphic units (Table 1 in GABRIEL et al. 2008). In this routine, "Quaternary“ and „Pliocene“ are defined by their sediment provenance (e.g. BARTZ 1982, HGK Rhein-Neckar 1999). I.e. „Pleistocene“ Rhine sediments enclose material of alpine origin, „Pliocene“ sediments don't. This refers to a major event in the history of the alpine Rhine, when its course changed from "circumalpine" towards the North Sea (VILLINGER 1998).

In the URG, this provenance transition is usually a very distinct and widely recognized boundary. The alpine origin of the sediments above is easely detectable by carbonate content and identification of pebbles of alpine origin. It can further be proved by heavy mineral analysis (Boenigk 1987, Hagedorn 2004). According to the few yet available chronostratigraphic markers, the boundary is considered diachronic. The markers come from the non-alpine sediments below. They are located close to the present river Rhine and $30 \mathrm{~km}$ apart: In Sessenheim (25 km north of Strasbourg) the transition is identified still within the uppermost Neogene (Boenigk 1987), in Marlen (5 km south of Strasbourg) at least post-Tiglian (BROST \& ELLWANGER 1991, ElLWANGER 2003) or even postBavelian (BLUDAU 1998). In the far downriver Lower Rhine area, the provenance transition has been frequently detected as heavy mineral signal within the Pliocene Reuver Clay (BoENIGK 1970, 1987, Boenigk \& FreChen 2006, Kemna 2008, Kemna \& Westerhoff 2007, WESTERHOFF 2004, 2008).

In this paper we use the lithostratigraphic scheme outlined below (chapter 3.3), which has been created some years ago to avoid confusion. We also use chronostratigraphic terms, but only when referring to chronostratigraphy and only based on chronostratigraphic data.

\subsection{Sediment evaluation}

In Applied Geology, the Quaternary sediment succession of the URG is up to now described as an alternation of units of coarse and finegrained sediments (Kieslager, Zwischenhorizonte, BARTZ 1982). These units are widely used in e.g. in hydrogeology, serving as aquifer resp. aquitard units. Most data in archives fit in this routine.

In this paper we describe the succession as lithofacies resp. lithofacies associations and identify genetic units (FIEBIG 1999). We attempt to give a first interpretation of sedimentary cycles of various orders, stacking patterns and sedimentary control in different environments. Dealing with borehole cores of often quite coarse grained sediments, this is based primarily on first analysis of grain sizes, stratification, petrography, heavy minerals, carbonate content, pollen, molluscs, ichnofossils etc. Studies on stratification and textures are limited due to weak consolidation of the material.

We distinguish gravel, sand and fines (silt and clay) according to DIN 4022 and lithofacies terms according to Miall $(1985,1996)$. The succession is related to trends of the relative base level and the sediment input (a/s-ratio). They again depend on what is considered to ultimately control the sedimentary system: tectonic uplift and subsidence, compaction, but also effects of climate as intensified mechanical erosion.

The base level concept as applied here goes back to basic studies of Cross et al. (1993) and of Cross \& Lessenger (1998). They combine WALTHER's law with sediment volume partitioning. This leads to a simplified way to regard sedimentary cycles as a function of accommodation space vs. sediment supply (a/s-ratio). In particular the grain size variations and changes in the recorded environment are interpreted, e.g. sequences with dominant pedogenesis represent very low input and high accommodation space, i.e. high a/s-ratio; in contrast to sequences with dominant sand preservation in the fluvial system where the fines are reworked, i.e. low a/s-ratio. The changes of increase and 
decrease of the a/s-ratio are then used to identify the sequence stratigraphic frame which can be used for correlation.

\subsection{Lithostratigraphy}

The sedimentary succession is put in the frame of several lithostratigraphic units which were lately defined as formations and sub-formations (Fm, Sfm, Symbolschlüssel Geologie BAden-Württemberg 2007). They avoid the former mix-up with chronostratigraphy but, at the same time, try to continue to use major observations formerly registered. Primarily this concerns two observations: in the lower part of the succession the provenance change related to the alpine Rhine; and in the upper part (only northern URG) a specific boundary, revealing a wide-spread, externally controlled and abrupt change of lithofacies:

- Mannheim-Formation (upper unit), series of two or three sand cycles, low preservation potential of fines; topmost unit with increased ratio of local sand and gravel;

- Boundary: abrupt fine-coarse transition

- Kurpfalz-Formation (middle unit), series with basal coarse-fine-cycles of Rhenish provenance, followed by a sand-dominated section, and finally a widely recognized subunit of fines on top;

- Boundary: change of provenance;

- Iffezheim-Formation (lower unit), series of sand-to-mud cycles of local origin, usually including strongly weathered sediments.

The above patterns reflect the lithofacies of the central HDB. They are modified by local input, in this case of the Neckar close to Heidelberg. Please note that in the frame set up by these definitions,

- Provenance plays no part with regard to the upper boundary (Kurpfalz-Formation vs. Mannheim-Formation);

- Lithofacies plays no part with regard to the lower boundary (Iffezheim-Formation vs. Kurpfalz-Formation); and

- Chronostratigraphy plays no part with regard to both boundaries.

\section{The Heidelberg Cores - Description and basic classifications (Litho- and Biostratigraphy)}

\subsection{Some general remarks}

The Heidelberg research boreholes are the deepest in the project, representing the depocentre on the eastern margin of the HDB. They are located just north of the Campus of Heidelberg University, still close to the mouth of the River Neckar in downtown Heidelberg, and situated on the alluvial fan of the Neckar. For technical reasons, a first borehole was cored to $190 \mathrm{~m}$, a second borehole from 184 to $500 \mathrm{~m}$ (UniNord 1+2). The two sites are only $300 \mathrm{~m}$ apart and are easily correlated (Fig. 2). Their combined depth of $500 \mathrm{~m}$ exhibits Quaternary sediments down to $\sim 500 \mathrm{~m}$ which is more than originally predicted (before drilling the chronostratigraphic Plio- Pleistocene transition was expected around $400 \mathrm{~m}$, i.e. we intended to recover $400 \mathrm{~m}$ cores of Quaternary sediments, plus $100 \mathrm{~m}$ of Pliocene sediments).

We present a condensed lithostratigraphic description and classification of the sediments, including some remarks on

- sediment provenance, derived from pebble and heavy minerals analysis;

- the sedimentary environment;

- the few already available biostratigraphic markers, derived from pollen analysis, that are used to set up a chronostratigraphic frame;

- and depositional trends.

Following the conventional technique of core documentation, the major units are in order from top to bottom; but subunits in upward direction. A detailed description including further data will be published later in a special volume of LGRB Informationen (Regierungspräsidium Freiburg, www.rp-freiburg.de).

The sediment succession is provisionally subdivided in three large units according to the above lithostratigraphic terms. At UniNord they were identified as follows:

- Mannheim-Formation from 56 to $0 \mathrm{~m}$; as a series dominated by coarse gravels, with layers of diamicton and fines, including a well preserved fossil soil; 


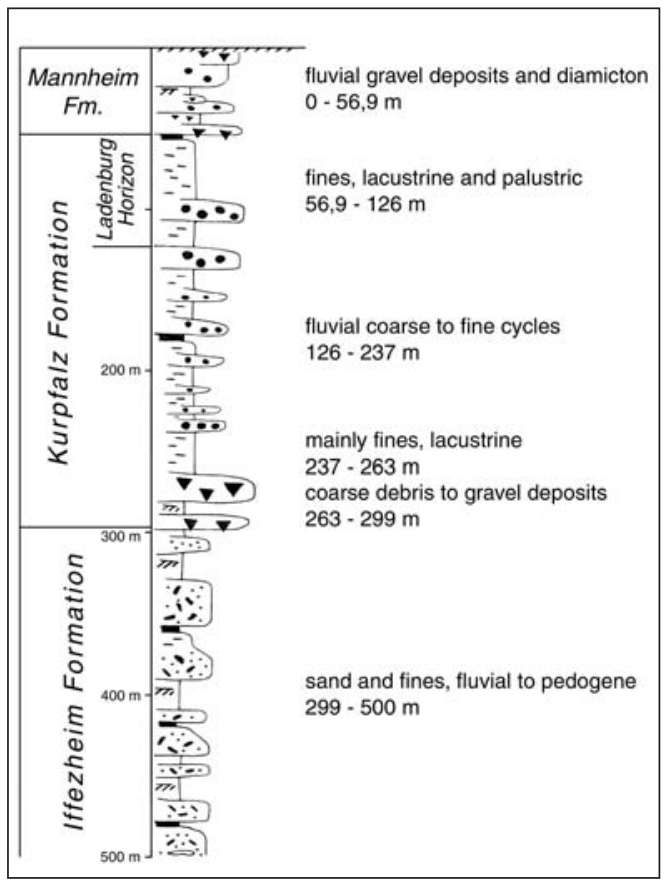

Fig 2: Overview of the sediment succession of the Heidelberg deep down to $500 \mathrm{~m}$, comprised from the UniNord boreholes of 2006 (interval from 0 to $190 \mathrm{~m}$ ) and of 2008 (interval from $184 \mathrm{~m}$ to $500 \mathrm{~m}$ ). Lithostratigraphic frame, major lithologies and sedimentary environments. Legend cf. Fig. 3.

Abb. 2: Übersicht der Sediment-Abfolge im Heidelberger Loch bis $500 \mathrm{~m}$ Tiefe, zusammengesetzt aus den Bohrungen UniNord aus 2006 (Abschnitt von 0 bis $190 \mathrm{~m}$ ) und aus 2008 (Abschnitt von $184 \mathrm{~m}$ bis $500 \mathrm{~m}$ ). Lithostratigraphischer Rahmen, vorherrschende Lithologie und Ablagerungsmilieu. Legende vgl. Abb. 3.

- Boundary: abrupt transition of fine-coarse sedimentation

- Kurpfalz-Formation from 299 to $56 \mathrm{~m}$; as a series with coarse debris at the basis (subunit K1); a two-parted main section with coarse debris and gravel, sand and fines in the middle part; and a fine sediment dominated section on top;

- Boundary: change of provenance and abrupt transition of fine-coarse sedimentation

- Iffezheim-Formation from $>500$ to $299 \mathrm{~m}$; as a cyclic alternation of white-sand to clay and dark sand, altogether of non-alpine origin.

\subsection{Mannheim Formation at UniNord}

The Mannheim-Formation at UniNord covers the interval from 0 to $56 \mathrm{~m}$. The sediments are composed of about $75 \%$ coarse debris and gravel, $10 \%$ sand, $5 \%$ fines, and $10 \%$ diamicton. Fluvial gravels dominate. However, the succession begins and ends with a layer of coarse debris, the upper one resembling the alluvial fan of the Neckar which presently undergoes erosion and terrace formation. Within the gravels there are insertions dominated by diamicton; one of them grading into fines with a fossil soil.

The succession is stratified as follows (cf. Fig. 3):

- $0-12 \mathrm{~m}$ coarse debris with boulders,

- $12-26 \mathrm{~m} \quad$ fluvial gravel with some

- 26-34 m diamicton with sand cover;

- $34-38 \mathrm{~m}$ diamicton grading into mud

- $38-46 \mathrm{~m} \quad$ fluvial gravel;

- 46-48 m diamicton;

- $48-55 \mathrm{~m} \quad$ fluvial gravel;

- $55-56 \mathrm{~m} \quad$ coarse debris and gravel;

Provenance: The petrographic spectra of the gravels reflect the up-river catchment of the present Neckar valley passing through the Odenwald highlands. There are large components of the nearby Buntsandstein which are coarse and poorly rounded. The Muschelkalk components are usually finer and better rounded; however, one boulder occurs at the basis of the unit at $56 \mathrm{~m}$. Some small components come from the far distant Neckar catchment, i.e. the Jurassic of the Swabian Alb. The crystalline basement with the nearby major exposure below Heidelberg castle is only poorly represented. - Most sand and fines are also of Neckar provenance, with the exception of several sand-rich strata resembling traces of Rhenish provenance by their instable heavy mineral composition. They are very well sorted and therefore supposed to come from reworked eolian input, alike to the nearby dunes, and may represent elder phases of cold climate $(26-29 \mathrm{~m})$. 

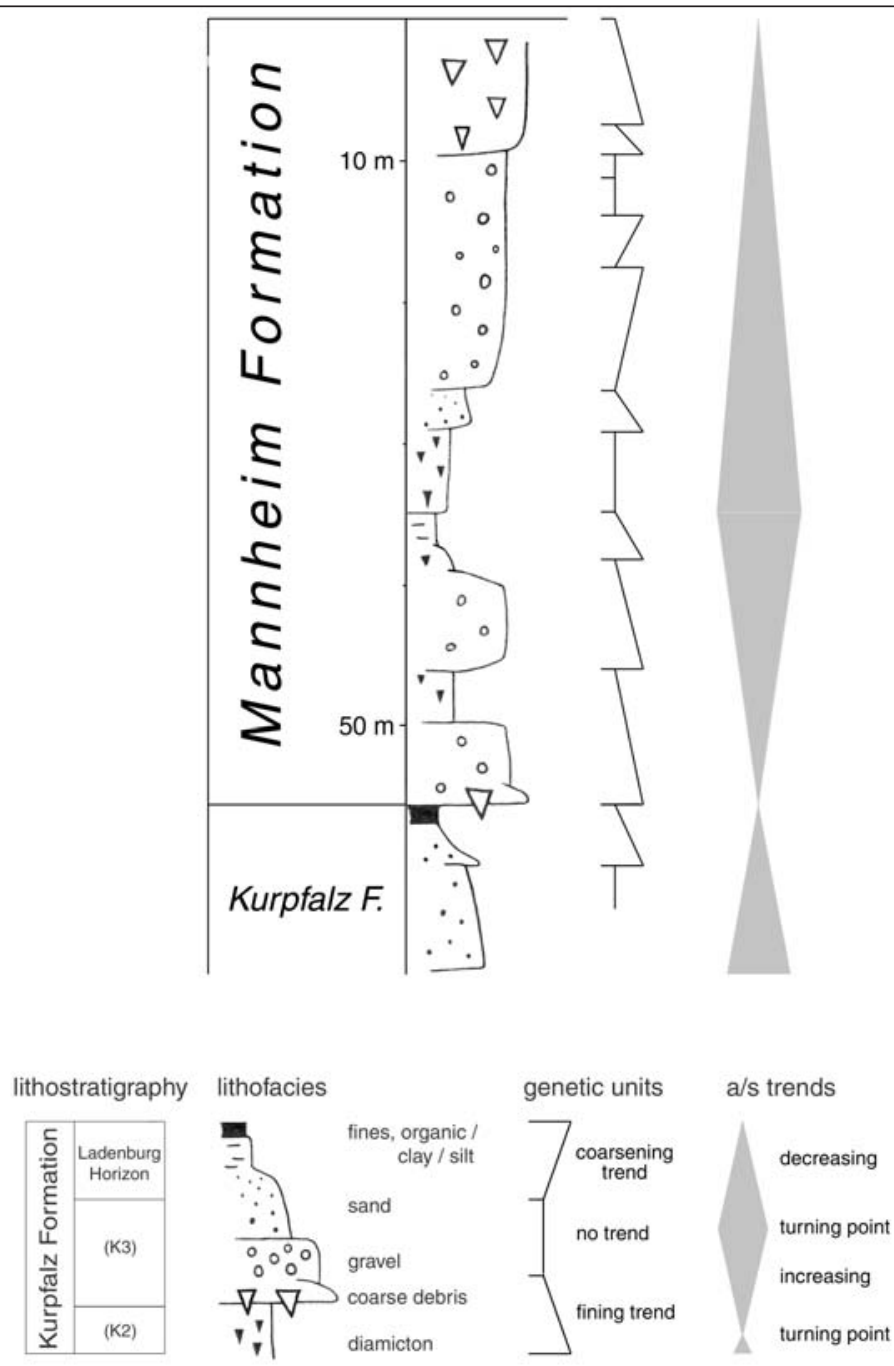

Fig. 3: The sediment succession of the Mannheim-Formation in the Heidelberg UniNord research borehole (location Fig. 1).

Centre: Stratigraphic succession as Lithofacies log (schematic), genetic units; Left: Lithostratigraphic interpretation; Right: Sequence stratigraphic trends (increasing and decreasing a/s-ratio).

The succession is dominated by coarse debris flows and proximal fluvial gravels, but also includes insertions of matrix-rich diamicton and fine sediments. - Further details on the stratigraphic succession, provenance, chronostratigraphic markers and sedimentary environment see text.

Abb. 3: Die Sedimentfolge der Mannheim-Formation aus der Forschungsbohrung Heidelberg UniNord (Lokation Abb. 1):

Mitte: Stratigraphische Abfolge als schematisches Lithfazieslog, genetische Einheiten; Links: Lithostratigraphische Interpretation; Rechts: Sequenzstratigraphische Trends (zu- und abnehmendes a/s-Verhältnis).

Die Abfolge wird beherrscht von groben Debris-Flows und proximalen Flussschottern; sie enthält auch Einschaltungen von Matrix-reichen Diamikten und Feinsedimenten. - Weitere Angaben zur Schichtenfolge, Provenienz, chronostratigraphischen Marken und Ablagerungsmilieu im Text. 
Sedimentation: The depocentre of the HDB corresponds with the alluvial fan of the Neckar. The genetic units in intervals with coarse debris and fluvial gravels match well with this proximal setting (Fig. 3). One major interval with diamicton, fines and pedogenesis, occurs all over the depocentre (HGK 1999). As a result, the Mannheim-Fm shows an overall coarse - fine - coarse trend, going along with a first increasing then decreasing a/s-ratio. Any further interpretation needs a chronostratigraphic frame.

Chronostratigraphy: No chronostratigraphic markers are yet available. As the underlying unit (Ladenburg-Subformation) is supposed to date from the Cromerian, post-Cromerian ages are expected. The fossil soil at $34 \mathrm{~m}$ is quite well preserved, dividing the succession into an upper and a lower part. Their interpretation remains open (last and penultimate glaciation, effects of loading and compaction).

Summary and interpretation: The major part of the Mannheim-Formation at the Heidelberg UniNord borehole is built up by coarse sediments representing the proximal lithofacies of the Neckar alluvial fan. This is an inputcontrolled system which strongly depends on sediment supply from the nearby Odenwald highlands. As preservation in superposition is discontinuous, due to lateral shifting within the fan, the subsidence of the basin plays only a minor part.

\subsection{Kurpfalz Formation at UniNord}

The Kurpfalz-Formation at UniNord covers the interval from 299 to $56 \mathrm{~m}$, i.e. its thickness amounts to $243 \mathrm{~m}$. It is composed of $35 \%$ debris and gravel, $20 \%$ sand, and $45 \%$ fines. There is a continuous background supply and preservation of fine sediments (lacustrine, fluvial overbanks), interrupted by three major intervals with coarse debris and gravel input (fluvial bedload, mass flow). Accordingly it is subdivided into lithostratigraphic subunits.

The uppermost subunit (interval 56 to $126 \mathrm{~m}$, Ladenburg-Subformation) is dominated by fine sediments. The subunit from 126 to $237 \mathrm{~m}$ (subunit K3) subsumes two pulses of coarse input (intervals $126-168 \mathrm{~m}$ and 189 to 206 $\mathrm{m})$, but throughout with layers of fines and sand. The next subunit from 237 to $263 \mathrm{~m}$ is again wholly dominated by fine sediments (K2). Some genetic units grade into dark fines (organic), others into clay with evidence of pedogenesis and ichnofossils. The lowermost subunit $(263-299 \mathrm{~m}, \mathrm{~K} 1)$ is dominated by massive coarse debris $(263-288 \mathrm{~m})$ which represents the termination of a coarsening-up trend that begins with red sands below the Formation boundary at $316 \mathrm{~m}$. The definition of the lower boundary of the Kurpfalz-Formation is, as indicated above, not a matter of the local cycle architecture but of provenance. The lowermost signal of instable ,alpine“ heavy minerals has been identified at $292 \mathrm{~m}$; we suggest the Formation-basis at $299 \mathrm{~m}$.

The sediment succession of the Kurpfalz-Formation is stratified as follows (Fig. 4):

Ladenburg-Subformation from 56-126 $\mathrm{m}=$ $70 \mathrm{~m}$ (20\% gravel, $10 \%$ sand, $70 \%$ fines $)$

- 56-67 m graded sand to fines and fossil peat, fluvial, some sand from eolian input and fluvially reworked;

- 67 - $74 \mathrm{~m}$ massive fines, lacustrine;

- 74-80 m graded sand to fines;

- $80-83 \mathrm{~m} \quad$ silt and clay, ichnofossils, fossil soil, fluvial environment;

- 83 - $89 \mathrm{~m}$ massive fines, lacustrine;

- 89-92 m gravely sands, ?diamicton;

- $92-101 \mathrm{~m} \quad$ gravel, some sand from eolian input and fluvially reworked, ?diamicton (no or poor cores);

- $101-103 \mathrm{~m} \quad$ fines and sand, gravely, ?diamicton (poor cores);

- 103 - 109 m coarse debris, gravel, sand, ?diamicton (poor cores);

- $109-126 \mathrm{~m}$ massive fines, at the basis with coarse components, lacustrine; 

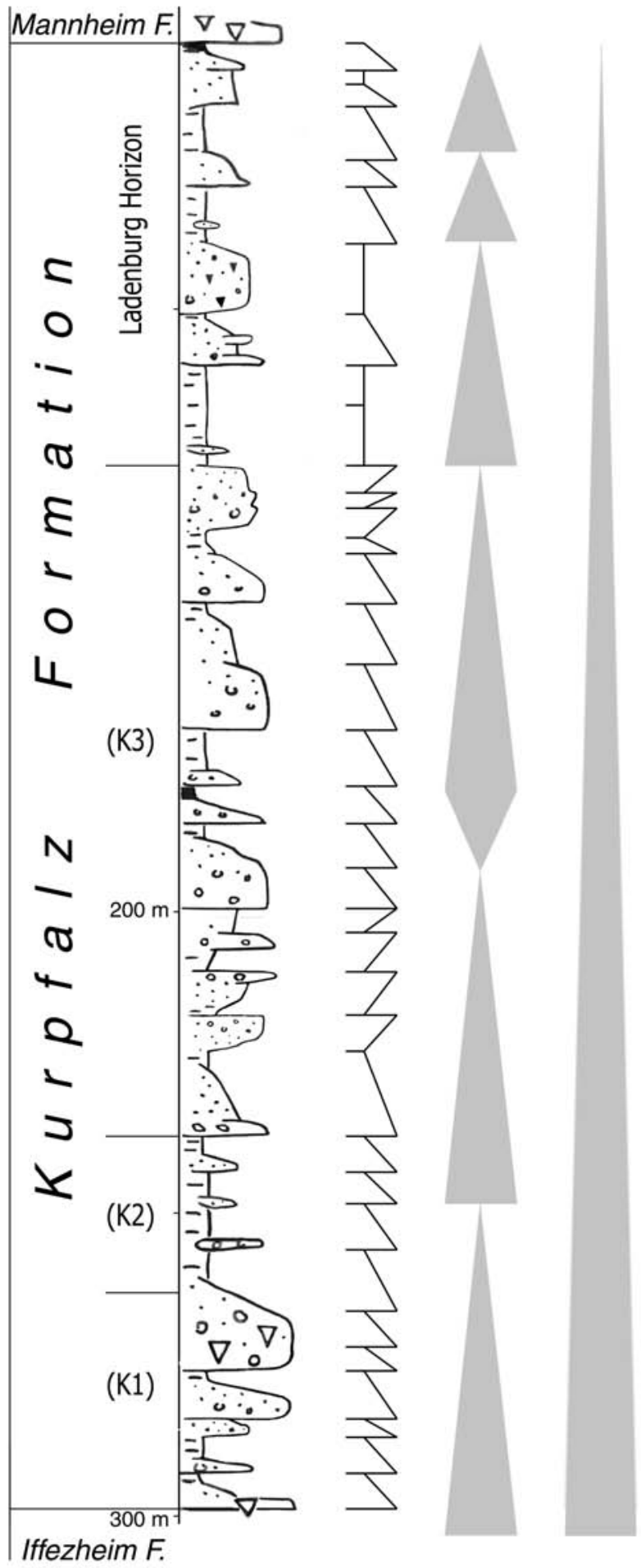

Fig 4: The sediment succession of the Kurpfalz-Formation in the Heidelberg UniNord research borehole (location Fig. 1).

Centre: Stratigraphic succession as Lithofacies log (schematic), genetic units;

Left: Lithostratigraphic interpretation (Formation and sub-units);

Right: Medium and large scale sequence stratigraphic trends.

The succession begins with sediments reflecting a lacustrine environment, with and without coarse mass flow insertions (K1, K2). It grades up into fluvial overbanks and gravels (lower K3) and a prograding system of fluvial gravels (upper $\mathrm{K} 3$ ). After abrupt change, the pattern is twice repeated on smaller scale (Ladenburg-Horizon). - Further details on the stratigraphic succession, provenance, chronostratigraphic markers and sedimentary environment see text. Legend cf. Fig. 3.

Abb. 4: Die Sedimentfolge der KurpfalzFormation aus der Forschungsbohrung Heidelberg UniNord (Lokation Abb. 1):

Mitte: Stratigraphische Abfolge als schematisches Lithfazieslog, genetische Einheiten

Links: Lithostratigraphische Interpretation (Formation und Untereinheiten);

Rechts: Sequenzstratigraphische Trends mittlerer und großer Ordnung.

Die Abfolge beginnt mit lakustrinen Sedimenten, zunächst mit, dann ohne Grobsediment-Einschaltungen (K1, K2). Darüber fluviale Overbank-Sedimente und Schotter (K3 unterer Teil) und schließlich ein progradierendes System fluvialer Schotter (K3 oberer Teil). Nach einem abrupten Wechsel wiederholt sich dasselbe Muster in kleinerer Ordnung zwei Mal (Ladenburg-Horizont). - Weitere Angaben zur Schichtenfolge, Provenienz, chronostratigraphischen Marken und Ablagerungsmilieu im Text. Legende vgl. Abb. 3. 
Section (K3) from $126-237 \mathrm{~m}=111 \mathrm{~m}$ (35\% gravel, $30 \%$ sand, $35 \%$ fines)

- $126-138 \mathrm{~m}$ sand, gravel, debris (no or poor cores recovered);

- $138-152 \mathrm{~m} \quad$ sand and gravel with some fines (no or poor cores recovered);

- $152-168 \mathrm{~m} \quad$ sand and gravel (no or poor cores recovered), basis of subunit K3b;

- $168-179 \mathrm{~m}$ massive fines upon insertion of sandy gravel;

- $179-185 \mathrm{~m}$ cycle of gravel-sand-fines-peat;

- $185-206 \mathrm{~m}$ basal debris, gravel, red sand and nes, Kła;

- $206-211 \mathrm{~m}$ gravely sand and fines;

- $211-215 \mathrm{~m}$ sand;

- 215 - $217 \mathrm{~m}$ fines, fossil soil;

- 217 - $222 \mathrm{~m}$ gravel, debris;

- 222 - $227 \mathrm{~m}$ fines, fossil soil;

- $227-234 \mathrm{~m}$ grey and red sand;

- $234-237 \mathrm{~m} \quad$ coarse debris grading into dark nes (organic);

Section (K2) from $237-263 \mathrm{~m}=26 \mathrm{~m}$ (10\% gravel, $15 \%$ sand, $75 \%$ fines) - $237-263 \mathrm{~m}$ fines, sandy to muddy, with few insertions of sand (254 - 257), gravel $(247-248)$ and debris (258 - 259), fossil soils;

Section (K1) from $263-299 \mathrm{~m}=36 \mathrm{~m}$ (60\% gravel and debris, $10 \%$ sand, $30 \%$ fines)

- $263-287 \mathrm{~m}$

debris of coarse gravels and some boulders, few layers of sand and fines;

- 287 - 297 m fines, silt and clay with ichnofossils, sand layers;

- 297 - 299 m debris of coarse gravels and some boulders.

Provenance: The sediment input in the Kurpfalz-Formation of the UniNord succession is classified in sediments of Rhine origin (i.e. comprising a signal of the alpine source area), of Neckar origin, and of very local origin. They may be subdivided in:

(a) fines and sand of the Rhine (proven by instable heavy mineral ratio $>50 \%$ );

(b) local or Neckar fines and sand (instable heavy mineral ratio $<50 \%$ );

(c) gravel of the Neckar (pebbles of Buntsandstein, Muschelkalk and Jurassic); and

(d) coarse debris and gravel of the nearby Odenwald (mainly Buntsandstein, some crystalline and Muschelkalk).

The sediments of the Ladenburg-Subformation belong primarily to the ,fines and sands of Neckar or local origin“. There are exceptions at the top of two lacustrine intervals, where minor sand pulses of Rhine origin are identified by their instable heavy mineral content. Presently we interpret this to be fluvially reworked eolian input. - The Ladenburg-deposits of UniNord are contemporaneous with similar deposits all over the HDB which are usually of Rhine origin. They also correlate with the upstream buried valley infill at the discovery site of the Homo heidelbergensis located near to the village of Mauer, some $15 \mathrm{~km}$ southeast of UniNord (LÖSCHER 1996). From this it follows that the sediment of this subunit covered the whole HDB, and extended beyond the Eastern Boundary Fault $(\mathrm{EBF})$ of the URG. I.e. the nearby Neckar valley within the Odenwald highlands is also, as a drowned valley, part of the basin.

The subunits $\mathrm{K} 1$ and the lower part of K3 show strong evidence of periodical fluvial input from the alpine Rhine, with continuous input from the Neckar upheld. In K1, the arrival of the Rhine and the preservation of fines even when alternating with coarse local sediments indicate a strongly increasing a/s-ratio. In K2, only sand on fines of non-Rhine origin are yet identified. The K3 succession begins with an alternation of local and Rhine input. Then the local input is gradually replaced by supply from the Neckar, and still further up the input from the Rhine terminates. From 190 m upwards only sediments of Neckar provenance are left.

The three intervals of coarse debris and gravel (subunits $\mathrm{K} 1$ and $\mathrm{K} 3$ ) refer to expanding erosion into the Odenwald, probably due to uplift. 
There is always an overall dominance of coarse Buntsandstein, but the ratio of the supplementary components varies (Muschelkalk, crystalline). The first coarse pulse $(299-297 \mathrm{~m}$, basis of K1) contains much local crystalline (Heidelberg Granite). The main pulse $(287-263 \mathrm{~m})$ is mainly Buntsandstein, but with an upward increasing ratio of Muschelkalk; i.e. the sediment source is first „downtown Heidelberg“, then expanding towards the Muschelkalk scarp. - Two coarse intervals of fluvial gravels follow (206 - $189 \mathrm{~m}$ and $168-126 \mathrm{~m}$, subunit K3). Within the latter a first small then increasing ratio of Jurassic is present, and there are some layers where the Muschelkalk components dominate. This is also characteristic regarding some correlative gravely insertions in the succession of the Viernheim sister drilling (interval 180 to $80 \mathrm{~m}$, Hoselmann 2008).

Sedimentation: The overall fluvial evolution of the UniNord succession is interrupted in the Kurpfalz-Formation by intervals of lacustrine conditions and by intervals of strong supply of mass flows. Our interpretation as a lacustrine environment is based upon the abrupt occurance of coarse-grained debris flows within the fine-grained background sedimentation. In some parts of the succession, even matrix supported mass flow deposits including boulders and cobbles occur (high density mass flows). The abrupt alternation of mass flow- and background-sedimentation is a clear indication for lacustrine deposition in a lake system with a minimal water depth of several meters.

The first lacustrine interval is at the basis of the Formation where mass flow deposits of coarse debris are embedded in fines, with almost no transition (subunit K1). It carries on in subunit $\mathrm{K} 2$ with few coarse layers in the fines. Eventually the lacustrine sedimentation terminates, first indicated by fossil soils in the fines (transition of subunits K2 to K3), then by cycles of fluvial gravels to fines (subunit K3). The lower gravel seems to represent a local event; the upper reflects a long and overall coarsening-up series of a prograding fluvial system. - The transition to follow, from fluvial gravels to the fines of the Ladenburg-Subformation, is again very abrupt. The fines are massive; again with insertions of mass flow deposits (here the components are well rounded i.e. reworked from the gravels). This again represents a lacustrine environment. Towards the top of these fines, the environment migrates back towards fluvial, first visible in traces of plant roots and ichnofossils, still within the fines, then by re-establishing the prograding fluvial system (lacustrine-to-fluvial cycle from 126 to $89 \mathrm{~m}$ $=37 \mathrm{~m}$ ). In the upper part of the LadenburgSubformation, two more lacustrine to fluvial transitions are identified $(89-74 \mathrm{~m}=15 \mathrm{~m}$; and $74-56 \mathrm{~m}=18 \mathrm{~m}$ ). They range from massive fines up to graded sands, i.e. they comprise no gravely sediments. Further up, the lacustrine to fluvial cyclicity is drowned by the input of the Mannheim-Formation.

The Kurpfalz-Formation shows an overall decreasing a/s-ratio throughout the succession, with various symmetrical and asymmetrical cycles of lower order (Fig. 4). The maximum accommodation space is given in the first lacustrine cycle (K1, K2), which hosts not only coarse local debris but also alpine sands of the Rhine. The alpine influence is then pushed back by prograding coarse-grained fluvial Neckar deposits (K3).

Chronostratigraphy: Some biostratigraphic markers based on pollen analysis are already available. They are preliminarily interpreted.

- At $57-70 \mathrm{~m}$ and at $82-85 \mathrm{~m}$, ,coniferous forest": Interpretation: cool to cold ,interstadial" climate.

- At 81 - $82 \mathrm{~m}$ and at $87 \mathrm{~m}$, ,typical middle Pleistocene pollen spectra" but no Fagus and no early Pleistocene species. Interpretation: Cromerian.

- At 162 - 163 m, pollen spectra with Pinus, Picea and Tsuga, no Carya, no Eucommia. Interpretation: Bavelian (per se uncertain, but in the succession quite likely).

- At 180 - $208 \mathrm{~m}$, pollen spectra with Tsuga and Pterocarya. Interpretation: Waalian (certain, Hahne, Ellwanger \& Stritzke 2008). 
- At 212 - 249 m ,coniferous forest“: Interpretation: rather cold climate, may match with the Eburon cold period.

The Cromerian age of the Ladenburg-Subformation was first published by ENGESSER \& MüNZING (1991); also the „Maurer Sande“ are of Cromerian age (LöSCHER 1996).

Summary and interpretation of the KurpfalzFormation: The succession of the Kurpfalz-Formation at UniNord, within its upper ,,sequence“"boundary and its lower, ,provenance"-boundary, comprises one overall large scale cycle, from a basal lacustrine environment up to a large and input controlled subunit of prograding fluvial gravels. The fines to follow are, although in parts lacustrine and related to a final pulse of subsidence, only of local importance. We suggest this has to do with the pattern of Rhine sediments through time in the HDB. This is confirmed by the sister boreholes of the Heidelberg project at Ludwigshafen and Viernheim, where, as it seems, the Rhine signal comes, in each case, at a different chronostratigraphic level.

- In Heidelberg, the overall depocentre of the HDB, the Rhine signal begins at $299 \mathrm{~m}$ (Eburonian) and ends at $190 \mathrm{~m}$ (Waalian);

- In Ludwigshafen at the western margin of the HDB, the Rhine signal begins at $177 \mathrm{~m}$ close to the Pliocene-Pleistocene transition (Weidenfeller \& KÄrCher 2008 and WeIDENFELLER \& KNIPPING 2008), then comes to a standstill (increase of local sediments with only stable heavy minerals) at 137 - $127 \mathrm{~m}$ and 109 - $97 \mathrm{~m}$ (Waalian);

- In Viernheim at the geographic centre of the HDB, the Rhine signal begins at $220 \mathrm{~m}$ (Hoselmann 2008, Knipping 2002, 2008). As discussed above we suggest correlating a subunit of prograding gravels from Heidelberg (Bavelian) with the $80-180 \mathrm{~m}$ interval at Viernheim. This leaves $40 \mathrm{~m}$ with little evidence of any greater hiatus. From all this we suggest the provenance change to happen in the Waalian.

The above may be interpreted as ,alpine“ Rhine sediments migrating in three steps through what later became the HDB: This story begins in Ludwigshafen close to the PliocenePleistocene transition; then it continues in Heidelberg in the Eburonian; and finally comes to Viernheim in the Waalian.

The subunit of prograding gravels (K3, Bavelian) appears to be the first unit covering the HDB in its present extent as a whole, as do the above units of the Ladenburg-Subformation and the Mannheim-Formation. Below the gravels (K3) there is a patchwork of local units which are difficult to correlate. Here the units including alpine Rhine sediments may be of small extend. Their west-to-east migration (from Ludwigshafen to Heidelberg) seems to be subsidence-controlled, as a result of the Halfgraben architecture. Their return back west to Viernheim is related to Neckar input. The upper units covering the entire HDB are related to input pulses of Rhine and Neckar which include potentially increased sediment volumes during the Pleistocene glaciations.

All sediments below the „alpine“ Rhine, regardless of their chronostratigraphic position, are not part of the Kurpfalz-Formation. They belong, to the Iffezheim-Formation.

\subsection{Iffezheim Formation at UniNord}

The Iffezheim-Formation at UniNord covers the interval from $>500$ to $299 \mathrm{~m}$, i.e. $>202 \mathrm{~m}$. It is a cyclic alternation of fluvial deposits with an average composition of $55 \%$ sand, and $45 \%$ fines. The succession is subdivided in several lithostratigraphic subunits, according to lithofacies variations. They are dominated by sand at 316 to $382 \mathrm{~m}$ (I5); by fine sediments at 382 to $411 \mathrm{~m}$ (I4); again by sand at 411 to $452 \mathrm{~m}$ (I3); fine sediments at 452 to 467 (I2); and finally by sand at 467 to $>500 \mathrm{~m}$ (I1). The uppermost subunit at 299 to $316 \mathrm{~m}$ (I6) resembles the transition to the lacustrine environment and to the onset of coarse local debris of subunit (K1).

The main fluvial lithofacies are:

- Grey, coarse to medium-grained sands. They contain only few gravely components, the small pebbles being well rounded and often with weathering halos. Quite frequently there are other coarse components, 
as pieces of wood of various size (in the cores with diameters up to $25 \mathrm{~cm}$ ), but also reworked pieces of fine sediment, ranging from small rounded pieces up to large strata. Their original stratification may be preserved, including organic-rich laminae or even peat. They were probably in a frozen state during transport.

- White, fine to medium-grained sands, usually very well sorted. They either alternate with the grey sand lithofacies, or grade into green silt with sandy laminations, and finally into the silt and clay cycles.

- Clay-rich overbank fines, forming sequences of green and sandy silt grading into clay-rich silt up to almost pure clay, usually speckled with brownish (wet) and reddish (dry) colours resembling pedogenesis. Colours are intense, apart from the transition to the Kurpfalz-Formation where they become dark and gloomy. The sequences are rich in ichnofossils, in some layers also in authigenic grains (authigenic siderite, Dr. Martin, Freiburg). Some are fractured due to diagenetic compaction.

The sediment succession of the Iffezheim-Formation is stratified as follows (cf. Fig. 5):

Section (I6) from 299 to $316 \mathrm{~m}=17 \mathrm{~m}$ (55\% sand and $45 \%$ fines)

- $\quad 299$ - $305 \mathrm{~m}$ dark fines, sandy silt to clay;

- $\quad 305-316$ m massive dark grey sand and graded dark red sand;

Section (I5) from $316-382 \mathrm{~m}=66 \mathrm{~m}$ (65\% sand and $35 \%$ fines)

- $316-323 \mathrm{~m}$ fines (sandy silt to clay with organic-rich top);

- $\quad 323-329$ m brightly coloured fines (sandy silt to clay);

- $\quad 329-340 \mathrm{~m}$ alternation of

- grey sand with reworked wood and fines, and of

- white sand with kaolin;

- $\quad 340-342 \mathrm{~m}$ brightly coloured silt and clay, ichnofossils;

- $\quad 342-351 \mathrm{~m}$ grey sand with reworked wood and fines;
- $\quad 351-382 \mathrm{~m}$ grey sand with reworked wood and fines;

Section (I4) from $382-411 \mathrm{~m}=29 \mathrm{~m}$

(10\% sand and $90 \%$ fines)

- $\quad 382-399 \mathrm{~m}$ fines, green silt to coloured clay with ichnofossils and brown and red fossil soils;

- $\quad 399-402 \mathrm{~m}$ white sand and grey silt;

- $402-411 \mathrm{~m}$ brightly coloured fines, green silt to coloured clay with ichnofossils and brown and red fossil soils;

Section (I3) from $411-451 \mathrm{~m}=40 \mathrm{~m}$ (70\% sand and $30 \%$ fines)

- 411-421 m grey sand with reworked wood and fines, grading into white sand;

- $\quad 421-425 \mathrm{~m}$ white sand grading into silt and clay with ichnofossils;

- 425-440 m alternation of - grey sand with reworked wood and fines, and of - white sand with kaolin matrix;

- $\quad 440-443 \mathrm{~m}$ brightly coloured silt and clay with ichnofossils;

- 443-451 m alternation of - grey sand with reworked wood and fines, and of - white sand with kaolin matrix (445 - 447); - fines, laminated with white sand (443 - 445);

Section (I2) from $451-467 \mathrm{~m}=16 \mathrm{~m}$ (almost $100 \%$ fines)

- $451-467 \mathrm{~m}$ brightly coloured fines, green silt to coloured clay with ichnofossils and brown and red fossil soils;

Section (I1) from $467-500 \mathrm{~m}=33 \mathrm{~m}$ (80\% sand and $20 \%$ fines)

- 467 - >500 m grey sand with reworked wood and fines; 

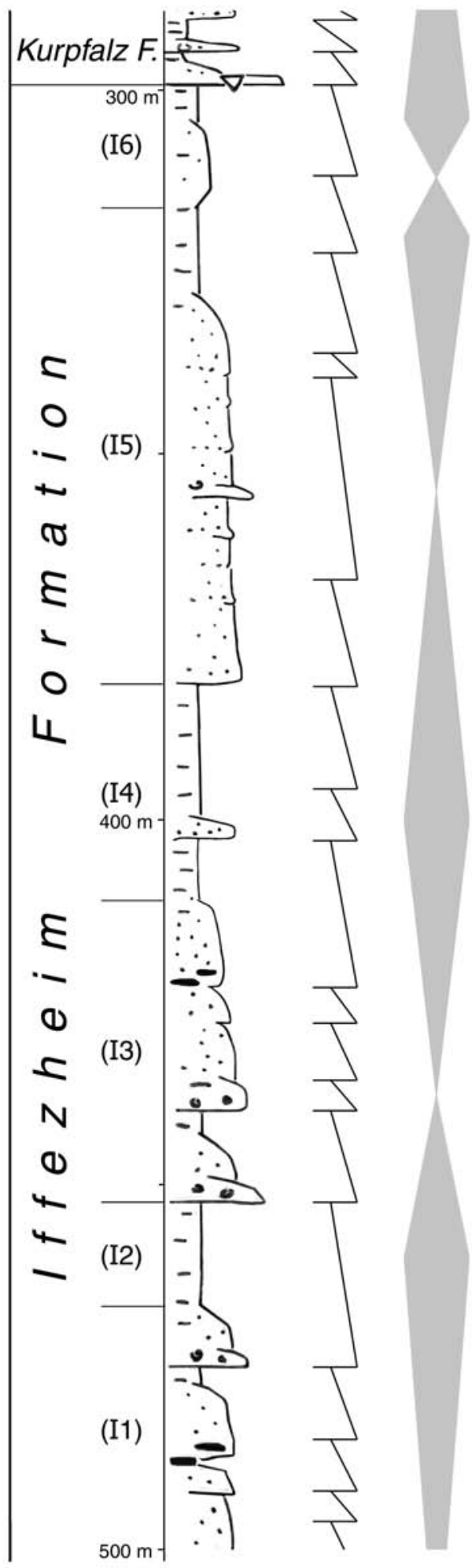

Fig. 5: The sediment succession of the IffezheimFormation in the Heidelberg UniNord research borehole (location Fig. 1).

Centre: Stratigraphic succession as Lithofacies log (schematic), genetic units;

Left: Lithostratigraphic interpretation (Formation and sub-units);

Right: Sequence stratigraphic trends (increasing and decreasing a/s-ratio).

The succession (I1 - I5) is composed of alternating fluvial bedload sands and overbank silt and clay. The sands contain large pieces of reworked overbank fines, the silt and clays are frequently altered by ichnofossils and pedogenesis. The uppermost unit (I6) includes proximal local sand insertions reflecting the beginning of local mass flow as in unit K1. - Further details on the stratigraphic succession, provenance, chronostratigraphic markers and sedimentary environment see text. Legend cf. Fig. 3.

Abb. 5: Die Sedimentfolge der Iffezheim-Formation aus der Forschungsbohrung Heidelberg UniNord (Lokation Abb. 1):

Mitte: Stratigraphische Abfolge als schematisches Lithfazieslog, genetische Einheiten

Links: Lithostratigraphische Interpretation (Formation und Untereinheiten);

Rechts: Sequenzstratigraphische Trends (zu- und abnehmendes a/s-Verhältnis).

Die Abfolge (I1 - I5) besteht aus fluvialen Sanden (bedload) und schluffig-tonigen Overbank-Schichten. In den Sanden sind große Feinsedimentstücke aufgearbeitet, während die Overbanks durch Spurenfossilien und Bodenbildung verändert sind. In der obersten Einheit (I6) sind proximale Lokalsande eingeschaltet, die zu den Massflows der darüber folgenden Einheit K1 überleiten. - Weitere Angaben zur Schichtenfolge, Provenienz, chronostratigraphischen Marken und Ablagerungsmilieu im Text. Legende vgl. Abb. 3. 
Provenance: The „local“ i.e. non-alpine origin of the sediments determines their allocation to the Iffezheim-Formation. This is primarily based on heavy mineral analysis. Many of the few coarser components are of Buntsandstein origin, as are several layers of red sands. - The provenance of the other sediments remains uncertain. The well sorted white sands are probably far transported, but this may be an inherited feature if they are reworked from nearby Neogene sands. The grey sands are related to various sources, including crystalline and Buntsandstein (Odenwald? Black Forest?). They seem confined to a fluvial system close to the eastern margin of the URG. The source of the silt and clay is again undetermined, probably nearby Neogene.

Sedimentation: By alternation of the grey sand lithofacies and the silt-to-clay lithofacies, several genetic units are stacked to symmetrical cycles of increasing and decreasing a/s-ratios. Within the fines, the turning points often coincide with intensive pedogenesis i.e. almost no input; within the sands they coincide with sections where large pieces of reworked fines indicate a/s minima. These bedload-dominated units represent the greater part of the succession. The preserved cycles are in the 10 to $50 \mathrm{~m}$ order. - The minima of accommodation space are likely to be related with increasing sediment supply, maybe due increased sediment volumes as a result of colder climate (some of the reworked fines are still stratified, they may have been frozen when redeposited). As opposed to this the sediment input is generally much reduced in silt-clay sections, with ichnofossils and traces of more or less reworked fossil soils. Preservation is primarily related to local subsidence of the depocentre, but differentiated uplift within and at the northern margin of the URG may also be involved.

Chronostratigraphy: Some biostratigraphic markers based on pollen analysis are already available. They are preliminarily interpreted.

- At $312 \mathrm{~m}$, ,open coniferous forest with herbs". Interpretation: cool to cold climate (per se indifferent, but in the succession most likely Eburonian).

- At 316 m, „Pinus-dominated coniferous forest". Interpretation: cool to cold climate, could match with the Eburon cold period.

- At 358 - $359 \mathrm{~m}$, reworked strata. They host a pollen spectrum with $>30 \%$ ,tertiary taxa“ immediately overlying a typical „early Pleistocene pollen spectra“ with Fagus but no Tsuga. Interpretation: reworked Reuverian (Reuverian A) overlying reworked late Tiglian. Deposition age: late Tiglian to early Eburon.

- At 417-500 m (lowest sample at $499.94 \mathrm{~m}$ ): several typical ,early Pleistocene pollen spectra" with Fagus and tertiary taxa increasing downward, no Tsuga. Interpretation: Tiglian (certain) in stratigraphic superposition.

- At $481 \mathrm{~m}$ : „Pinus-dominated coniferous forest". Interpretation: cooler climatic period within the Tiglian (possibly Tiglian B, sensu Zagwisn 1963).

- There are no hints for in-situ sediments from the Pretiglian or Reuverian period. The reworked sample at $358 \mathrm{~m}$ illustrates the pollen spectra to be expected from insitu Reuverian.

Summary and interpretation of the cored part of the Iffezheim-Formation: According to the definition outlined above, the succession is not influenced by instable heavy minerals of the alpine Rhine. The above pollen markers show that the succession terminates well above the base of the Quaternary, i.e. in a time slice when the course of the alpine Rhine was already bound within the URG (in the western HDB proved by WEIDENFELLER \& KNIPPING 2008). At the same time, maximum sedimentation rates occur on the eastern side at Heidelberg UniNord. All this requires a two-partition of the HDB, with a western basin hosting the alpine Rhine, and an eastern basin with maximum sedimentation rates. The transition between the basins is suggested to be represented by the Viernheim drilling where the Rhine sediments arrived latest. 


\subsection{Below $500 \mathrm{~m}$}

As the cored UniNord boreholes end at $500 \mathrm{~m}$ still within the Tiglian, the lower part of the Tiglian, the Pretiglian, and the transition into the uppermost Neogene unit i.e. the Reuverian remain uncored. In order to estimate compaction and tectonic subsidence rates, serving as accomodation space of the cored units, some basic informations on the deeper subsurface are introduced here. They rely on three available data sets: (a) the sediment log of the „Radium Sol" borehole in downtown Heidelberg, approx. $1 \mathrm{~km}$ south of the UniNord location; (b) the ,vertical seismic profiling“ (VSP) log which was recorded by the Leibniz Institute for Applied Geophysics in the UniNord 1 borehole; and (c) the sediment log of the geothermal flush borehole from Weinheim, approx. $14 \mathrm{~km}$ north of UniNord.

(a) The Radium Sol drilling was finished in the early 1920ies (SALOMON 1927, BARTz 1951, FEZER 1998). Its overall cyclicality follows a coarse-fine-coarse pattern, with

$$
\begin{array}{ll}
\text { - } 0 \sim 350 \mathrm{~m} & \begin{array}{l}
\text { coarse and fine grained } \\
\text { sediments; } \\
\text { only fine grained } \\
\text { sediments; } \\
\text { - } 750 \sim 700 \sim 1000 \mathrm{~m}
\end{array} \\
\begin{array}{l}
\text { coarse and fine grained } \\
\text { sediments. }
\end{array}
\end{array}
$$

(b) The VSP log was recorded as part of the geophysical downhole logging program (data recorded down to $181 \mathrm{~m}$, velocity information to $160 \mathrm{~m}$ ). It is plotted as corridor stack down to $1000 \mathrm{~m}$ (BuNESS, pers. comm.). We do not interpret individual reflections but evaluate their frequency. There are many strong reflections in the upper part and again several though weaker reflections in the lower part, but almost none in a middle interval from 350 down to $700 \mathrm{~m}$. This is unlikely in a succession of alternating coarse and fine sediments. We conclude fine sediment dominance down to $770 \mathrm{~m}$.

(c) Also at Weinheim where two boreholes were flushed down to $\sim 1000 \mathrm{~m}$, a long interval of fine sediment domination has been detected down to $700 \mathrm{~m}$.
We conclude that, at UniNord, the high ratio of fine sediment will continue or even increase in the interval 500 to $700 \mathrm{~m}$, estimated $50 \%$ of fines or more. It will then again decrease in the 700 to $1000 \mathrm{~m}$ interval where coarse and fine sediments alternate. Assuming constant sedimentation rates as derived below, the transition from the Neogene Reuverian unit to the Pleistocene Pre-Tiglian stage is now predicted close to or below $600 \mathrm{~m}$.

\section{The Heidelberg Boreholes - Synopsis, Conclusions, Outlook}

\subsection{Sedimentation rates, Accommodation Space and Subsidence}

The patterns of Lithostratigraphy and Chronostratigraphy are compared in Table 1. Basically the lithostratigraphic boundaries are controlled by tectonics whereas Chronostratigraphy refers to climate. They are identical where the lithostratigraphy is based on the local lithofacies patterns, i.e. the boundaries of the Ladenburg-Sfm and the Mannheim-Fm.

Table 1 also includes ,absolute“ ages (STD 2002, OGg, OGG \& Gradstein 2008). They serve as a geochronologic frame to estimate average sedimentation rates for the units (Tab. 2, Fig. 6). They are, as yet, uncorrected, but may be used to calculate the non-tectonic i.e. compaction part of the subsidence.

\subsection{Input and uplift}

The local aspect: The relatively rapid increase of sediment thickness during Eburonian time is associated with coarse, clastic deposits. Clastic fragments are derived from Triassic sedimentary rocks and the Heidelberg granite and associated crystalline rocks of the Variscan basement. This sediment composition is interpreted to reflect the synchronous uplift of the adjacent rift shoulder and the initiation or reactivation of faults in the Heidelberg town area, which trend both subparallel with and at a high angle to the major, eastern rift bounding fault. Activities at these faults led to the exposition of the crystal- 
Table 1: Lithostratigraphy and Chronostratigraphy of the sediment succession of the borehole Heidelberg UniNord. The lithostratigraphic boundaries are controlled by tectonics (cf. Tab. 2); the chronostratigraphic stages refer to the alpine and north European glaciations and to the pollen-based biostratigraphy of NW-Europe. Sediment thicknesses are uncorrected.

Tab. 1: Lithostratigraphie und Chronostratigraphie der Sedimentfolge aus der Bohrung Heidelberg UniNord. Die lithostratigraphischen Grenzen sind tektonisch gesteuert (vgl. Tab. 2); die chronostratigraphischen Stufen beziehen sich auf die alpinen und nordeuropäischen Vergletscherungen und auf die pollenanalytisch begründete Biostratigraphie NW-Europas. Sedimentmächtigkeiten sind nicht korrigiert.

\begin{tabular}{|c|c|c|c|c|c|}
\hline \multicolumn{3}{|c|}{ Lithostratigraphy } & \multicolumn{3}{|c|}{ Chronostratigraphy } \\
\hline Formation & Sub-formation & $\begin{array}{l}\text { Interval } \\
\text { thickness }\end{array}$ & $\begin{array}{l}\text { original } \\
\text { Interval } \\
\text { thickness }\end{array}$ & Pollen & \\
\hline \multirow{4}{*}{$\begin{array}{l}\text { Mannheim-Fm } \\
0-56 \mathrm{~m}\end{array}$} & Neckar fan & $12 \mathrm{~m}$ & \multirow{4}{*}{$56 \mathrm{~m}$} & & \multirow{4}{*}{$\begin{array}{c}\text { Holocene; } \\
\text { Würm/Weichsel } \\
\text { Riss/Saale; } \\
\text { Hoßkirch/Elster }\end{array}$} \\
\hline & fluvial gravel & & & & \\
\hline & $\begin{array}{l}\text { Diamicton and } \\
\text { fines, } \\
\text { fossil soil }\end{array}$ & $44 \mathrm{~m}$ & & & \\
\hline & $\begin{array}{l}\text { fluvial gravel, } \\
\text { diamicton }\end{array}$ & & & & \\
\hline \multirow{6}{*}{$\begin{array}{l}\text { Kurpfalz-Fm } \\
56-299 \mathrm{~m}\end{array}$} & $\begin{array}{l}\text { Ladenburg- } \\
\text { Sfm (mass } \\
\text { flow, fluvial, } \\
\text { lacustrine) }\end{array}$ & $70 \mathrm{~m}$ & $70 \mathrm{~m}$ & & Cromerian \\
\hline & \multirow{3}{*}{$\begin{array}{l}\text { (K3) two } \\
\text { fluvial pulses } \\
126-237 \mathrm{~m}\end{array}$} & \multirow{3}{*}{$111 \mathrm{~m}$} & $44 \mathrm{~m}$ & $\begin{array}{c}\text { Pinus, Picea } \\
\text { Tsuga } \\
\end{array}$ & $\begin{array}{c}\text { Bavelian } \\
126-170 \mathrm{~m}\end{array}$ \\
\hline & & & $40 \mathrm{~m}$ & $\begin{array}{c}\text { Tsuga, } \\
\text { Pterocarya }\end{array}$ & $\begin{array}{c}\text { Waalian } \\
170-210 \mathrm{~m}\end{array}$ \\
\hline & & & \multirow{5}{*}{$130 \mathrm{~m}$} & $\begin{array}{l}\text { Coniferous forest } \\
210-250 \mathrm{~m}\end{array}$ & \multirow{5}{*}{$\begin{array}{c}\text { Eburonian } \\
210-340 \mathrm{~m}\end{array}$} \\
\hline & $\begin{array}{l}\text { (K2) lacustrine } \\
237-263 \mathrm{~m}\end{array}$ & $26 \mathrm{~m}$ & & & \\
\hline & $\begin{array}{l}\text { (K1) mass } \\
\text { flow, fluvial, } \\
\text { lacustrine, } \\
263-299 \mathrm{~m}\end{array}$ & $36 \mathrm{~m}$ & & No pollen & \\
\hline \multirow{7}{*}{$\begin{array}{l}\text { Iffezheim-Fm } \\
299-500 \mathrm{~m}\end{array}$} & $\begin{array}{l}\text { (I6) lacustrine } \\
\text { fines and Sand } \\
299-316 \mathrm{~m}\end{array}$ & $17 \mathrm{~m}$ & & $\begin{array}{l}\text { Open forest at } 312 \\
\mathrm{~m}\end{array}$ & \\
\hline & $\begin{array}{l}\text { (I5) fluvial } \\
\text { sand }\end{array}$ & $66 \mathrm{~m}$ & & $\begin{array}{c}\text { Coniferous forest } \\
\text { at } 316 \mathrm{~m}\end{array}$ & \\
\hline & $316-382 \mathrm{~m}$ & & \multirow{5}{*}{$160 \mathrm{~m}$} & \multirow{5}{*}{$\begin{array}{c}\text { early Pleistocene } \\
\text { pollen spectra } \\
\text { with Fagus and } \\
\text { Tertiary taxa } \\
\text { increasing } \\
\text { downward }\end{array}$} & \multirow{6}{*}{$\begin{array}{c}\text { Tiglian } \\
340->500 \mathrm{~m}\end{array}$} \\
\hline & $\begin{array}{l}\text { (I4) fluvial } \\
\text { overbank } \\
382-411 \mathrm{~m}\end{array}$ & $29 \mathrm{~m}$ & & & \\
\hline & $\begin{array}{l}\text { (I3) fluvial } \\
\text { sand } \\
411-451 \mathrm{~m}\end{array}$ & $40 \mathrm{~m}$ & & & \\
\hline & $\begin{array}{l}\text { (I2) fluvial } \\
\text { overbank } \\
451-467 \mathrm{~m}\end{array}$ & $16 \mathrm{~m}$ & & & \\
\hline & $\begin{array}{l}\text { (I1) fluvial } \\
\text { sand } \\
467-500 \mathrm{~m}\end{array}$ & $33 \mathrm{~m}$ & & & \\
\hline \multirow{3}{*}{$\begin{array}{l}\text { Not drilled: } \\
\text { Iffezheim-Fm } \\
500>700 \mathrm{~m}\end{array}$} & sand and fines & $?$ & $\begin{array}{l}\text { estimated } \\
20 \mathrm{~m}\end{array}$ & & \\
\hline & sand and fines & $?$ & $\begin{array}{l}\text { estimated } \\
80 \mathrm{~m}\end{array}$ & & Praetiglian \\
\hline & mainly fines & $?$ & $\begin{array}{c}\text { estimated } \\
>100 \mathrm{~m}\end{array}$ & & Reuverian \\
\hline
\end{tabular}


Table 2: Average sedimentation rates of the chronostratigraphic units, according to uncorrected thickness and age data of Table 1. Cf. Fig. 6.

Control of the subsidence: We suggest tectonic control only if the sedimentary environment relies on tectonic subsidence. This is, presently, only the case in the lacustrine intervals covering small areas in the Heidelberg deep (Eburonian, Cromerian). In all other cases we suggest that considerable parts of the accomodation space come up from compaction of underlying fine sediments. This will be considered in future studies, including correction of the sedimentation rates. - The discussion of the potential tectonic control of the input remains unaffected.

Tab. 2: Durchschnittliche Sedimentationsraten für die chronostratigraphischen Einheiten, unter Verwendung der unkorrigierten Sedimentmächtigkeiten und Altersdaten aus Tab. 1. Vgl. Abb. 6.

Steuerung der Subsidenz: Wir diskutieren eine tektonische Steuerung nur dann, wenn das Ablagerungsmilieu nicht anders hergeleitet werden kann. Das ist bisher nur in den lakustrinen Abschnitten der Fall, die nur kleinräumlich im Heidelberger Loch nachgewiesen sind (Eburon, Cromer). Ansonsten gehen wir derzeit davon aus, dass ein erheblicher Teil des Akkomodationsraums auch durch Kompaktion der Feinsedimente aus dem Liegenden herzuleiten ist. Bei der weiteren Bearbeitung sind die Sedimentationsraten entsprechend nach oben zu korrigieren. - Die potentielle tektonische Steuerung des Inputs bleibt unberührt.

\begin{tabular}{c|c|c|c|c|c|c}
$\begin{array}{c}\text { Chrono- } \\
\text { stratigraphy }\end{array}$ & $\begin{array}{c}\text { Sediment } \\
\text { Thickness }\end{array}$ & $\begin{array}{c}\text { Amount of fine } \\
\text { sediments }\end{array}$ & Duration & \multicolumn{2}{|c|}{$\begin{array}{c}\text { Sedimentation rates } \\
\text { (uncorrected) }\end{array}$} & $\begin{array}{c}\text { Suggested } \\
\text { major control of } \\
\text { Subsidence }\end{array}$ \\
\cline { 1 - 5 } $\begin{array}{c}\text { Würm, Riss, } \\
\text { Hosskirch }\end{array}$ & $56 \mathrm{~m}$ & $<5 \mathrm{~m}$ & $450 \mathrm{ka}$ & $56 / 450$ & 0.1 & Non-tectonic \\
\hline Cromerian & $70 \mathrm{~m}$ & $40 \mathrm{~m}$ & $350 \mathrm{ka}$ & $70 / 350$ & 0.2 & Tectonic \\
\hline Bavelian & $44 \mathrm{~m}$ & $5 \mathrm{~m}$ & $600 \mathrm{ka}$ & $44 / 600$ & $<0.1$ & Non-tectonic \\
\hline Waalian & $40 \mathrm{~m}$ & $15 \mathrm{~m}$ & $200 \mathrm{ka}$ & $40 / 200$ & 0.2 & non-tectonic \\
\hline Eburonian & $130 \mathrm{~m}$ & $70 \mathrm{~m}$ & $200 \mathrm{ka}$ & $130 / 200$ & 0.7 & Tectonic \\
\hline Tiglian & $160 \mathrm{~m}$ & $60 \mathrm{~m}$ & $600 \mathrm{ka}$ & $180 / 600$ & 0.3 & non-tectonic
\end{tabular}

line rocks, fragments of which are now found in the basin sequence. The subsequent period is characterized by thin sediments and may be related to a peneplanation observed at the rift shoulder. The ultimate stage, represented by the Mannheim Formation, with a more rapid increase in sediment thickness is lasting until the present and associated with renewed uplift of the rift shoulders. This uplift is accompanied by a dissection of the peneplain surface, caused by the reactivation of pre-existing faults.

The regional aspect: The first onset of alpine sedimentation in the HDB, as identified in the Ludwigshafen succession (WeIDENFELLER \& KNIPPING 2008) reflects the redirection of the al- pine Rhine into the URG, prior to the PliocenePleistocene transition at $\sim 2.6$ Ma (e.g. HoselMANN 2008). The redirection happens in the Mulhouse area where the first signal of alpine heavy minerals in the URG fill goes along with an abrupt coarsening of the lithofacies of alpine and local sediment. This composition has been interpreted as to reflect the starting uplift of parts of the southern Black Forest (ELLWANGER 2003), probably related to the latest folding in front of the Jura mountains (GIAMBONI et al. 2004).

Two subsequent uplift markers are identified in the UniNord succession. They are related to the coarse input at the basal Kurpfalz-Formation (Eburonian, $\sim 1.7 \mathrm{Ma}$ ) and to the coarse input 


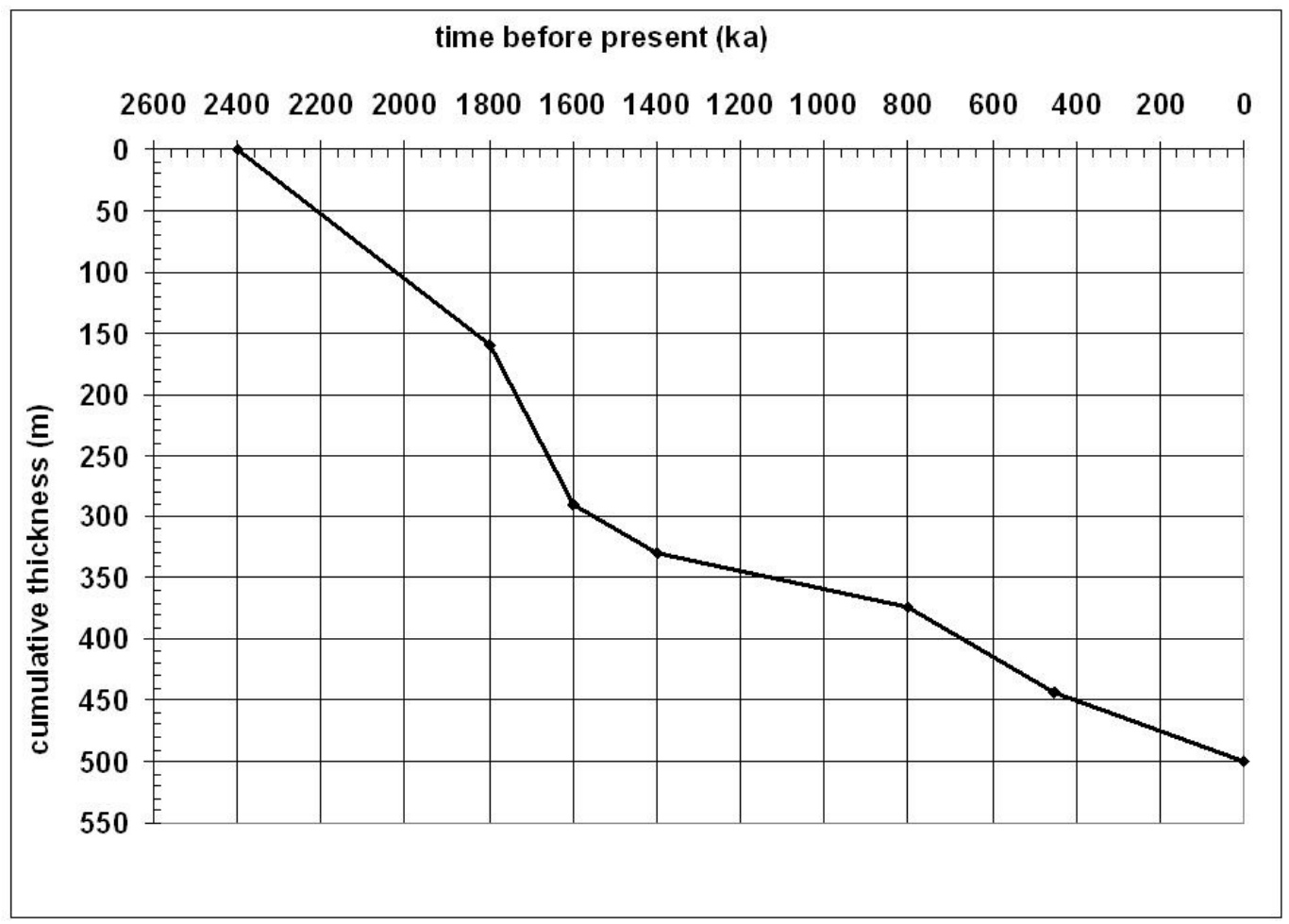

Fig. 6: Net accumulation of the sedimentary sequence through time of the Heidelberg UniNord borehole, using thickness and age data of Table 2 .

Abb. 6: Sedimentmächtigkeiten der Bohrung Heidelberg UniNord gegen stratigraphische Zeitskala, unter Verwendung unkorrigierter Mächtigkeiten und Alter aus Tab. 2.

at the basal Mannheim-Formation (post-Cromerian, $\sim 0.5 \mathrm{Ma}$ ). Both reflect uplift periods of the Odenwald. The post-Cromerian uplift is contemporaneous with the main uplift of the Rhenish Massif (cf. various studies of the lower main terrace e.g. Hoselmann 1994).

All this leads to a scenario of Quaternary uplift $=$ input events in cycles of $\sim 1 \mathrm{Ma}$, proceeding from south to north:

- $\sim 0.5 \mathrm{Ma} \quad$ Rhenish Massif plus

Odenwald (?plus Black

Forest);

- $\quad 1.7 \mathrm{Ma} \quad$ Odenwald (?plus Black

Forest);

- $\sim 2.6 \mathrm{Ma}$ southern Black Forest.

Each uplift event potentially provides sediment supply which will more easily be activated if the mechanical erosion is facilitated by climate changes (e.g. VANDENBERGHe 1993, 1995, BussCHERS 2007). In case of the middle input event the Tiglian to Eburonian transition is proved to occur well below the coarse input is recorded. This supports the above scenario. The other events lack of chronostratigraphic data.

\subsection{Outlook}

The descriptions, basic data and correlative patterns presented here are all focused upon the specific situation of the Heidelberg deep i.e. the cores of the borehole of the UniNord location in Heidelberg. In the interpretative steps to follow, the controlling parameters of sedimentation will have to be more thoroughly identified, 
e.g. are increasing a/s-ratios due to tectonic subsidence or to compaction within the basin, or due to uplift around the basin. This can only be accomplished if the entire HDB is regarded. Additional boreholes (e.g. Haimberger, Hoppe \& SCHÄFer 2005, Wirsing et al. 2007, HoselMANN 2008, HunZE \& WoniK 2008, Simon 2008, WeIDENFELLER \& KNIPPING 2008) as well as seismic and logging data (BunEss, Gabriel \& ELLWANGER 2008) will have to be included

\section{Acknowledgement}

The Heidelberg drilling project was greatly supported from many people and institutions. In first place the actual and former heads of the involved institutions, Prof. Dr. U. Yaramanci, Prof. Dr. H.-J. Kümpel, Prof. Dr. R. Watzel, Ltd. Bergdirektor V. Dennert and Prof. Dr. B. Stribrny. Dr. E. Würzner, Lord Major of the city of Heidelberg, arranged contacts, whenever necessary. The involved members of staff of the Stadtverwaltung Heidelberg, the Universitätsbauamt Heidelberg and the Amt für Vermögen und Bau Baden-Württemberg, Mannheim gave logistic support, provided the pieces of land for the Heidelberg boreholes and friendly helped whenever they could. All this support is gratefully acknowledged. Scientific discussions with colleagues helped significantly to become more familiar with several topics related to this project. Thanks to Dr. H. Buness, Dr. W. Engesser, Prof. Dr. M. Frechen, Dr. F. Fromm, Dr. C. Hoselmann, Dr. M. Martin, H. Meyer, Dr. Ch. Rolf, R. Thienel, Dr. M. Weidenfeller, Dr. T. Wonik and K. Worm. We very much thank Prof. Dr. Fiebig and an anonymous colleague for their reviews and additional valuable comments.

\section{References}

Bartz, J. (1951): Revision des Bohr-Profils der Heidelberger Radium-Sol-Therme. - Jahresberichte und Mitteilungen des Oberrheinischen Geologischen Vereins, 33: 101-125.

BArTZ, J. (1974): Die Mächtigkeit des Quartärs im Oberrheingraben. - In: Illies, J.H. \& Fuchs, K. (eds.): Approaches to Taphrogenesis: $78-87$.
BARTZ, J. (1982): Quartär und Jungtertiär II im Oberrheingraben im Großraum Karlsruhe. - Geologisches Jahrbuch, A 63: 2-237.

Bludau, W. (1998): Altpleistozäne Warmzeiten im Alpenvorland und im Oberrdheingraben - Ein Beitrag der Palynologie zum „Uhlenberg-Problem“. - Geologica Bavarica, 99: 119-133.

BoEnIGK, W. (1970): Zur Kenntnis des Altquartärs bei Brüggen. - Sonderveröffentlichungen Geologisches Institut Universität Köln, 17: 141 p.

BoenigK, W. (1987): Petrographische Untersuchungen jungtertiärer und quartärer Sedimente am linken Oberrhein. - Jahresberichte und Mitteilungen des Oberrheinischen Geologischen Vereins, N.F., 69: 357-394.

Boenigk, W. \& Frechen, M. (2006): The Pliocene and Quaternary Fluvial Archives of the Rhine System. - Quaternary Science Reviews, 25: 550-574.

Brost, E. \& Ellwanger, D. (1991), mit Beiträgen von W. Bludau \& C. Rolf: Einige Ergebnisse neuerer geoelektrischer und stratigraphischer Untersuchungen im Gebiet zwischen Kaiserstuhl und Kehl. - Geologisches Jahrbuch, E 48: 71-81.

Buness, H., Gabriel, G. \& Ellwanger, D. (2008): The Heidelberg Basin drilling project: Geophysical pre-site surveys. - Quaternary Science Journal (Eiszeitalter und Gegenwart), 57/3-4: 338-366.

Busschers, F. (2007): Unravelling the Rhine; response of a fluvial system to climate change, sea-level oscillation and glaciation. - PhD thesis Vrije Universiteit Amsterdam. Geology of the Netherlands 1: 1-183.

Cross, T.A., Baker, M.R., Chapin, M.A., Clark, M.S., Gardner, M.H., Hanson, M.S., LessEnger, M.A., Little, L.D., McDonough, K.J., Sonnefeld, M.D., Valasek, D.W., Williams, M.R. \& WritTeR, D.N. (1993): Application of high-resolution sequence stratigraphy to reservoir analysis. - In: Eschard, R. \& Doligez, B. (eds.): Subsurface Reservoir Characterization from Outcrop Observations. - Technip: 11-33.

Cross, T.A. \& Lessenger, M.A. (1998): Sediment Volume Partitioning: Rationale for Stratigraphic Model Evaluation and High-Resolution Stratigraphic Correlation. - In: SANDVIK, K.O., Gradstein, F. \& Milton, N. (eds.): Predictive high resolution sequence stratigraphy. - Norwegian Petroleum Society Special Publication: 171-196.

Deutsche Stratigraphische Kommission (2002): Stratigraphische Tabelle von Deutschland 2002 (STD 2002). 
Dèzes, P., Schmid, S.M. \& Ziegler, P.A. (2004): Evolution of the European Cenozoic Rift System: interaction of the alpine and Pyrenean orogens with their foreland lithosphere. - Tectonophysics, 389/1-2: 1-33.

DuRINGER, P. (1988) : Les conglomérats des bordures du rift cénozoïque rhénan. Dynamique sédimentaire et contrôle climatique. - Thèse d'Etat, Université de Strasbourg, $278 \mathrm{p}$.

Ellwanger, D., Fiebig, M., Gabriel, G., Hoselmann, C. \& Weidenfeller, M. (2007): Scientific Deep Drilling - The Heidelberg Basin Project. - Geophysical Research Abstracts, European Geosciences Union, 9: 09460-09460.

Ellwanger, D., Gabriel, G., Hoselmann, C., LämMERMANn-Barthel, J. \& Weidenfeller, M. (2005) : The Heidelberg Drilling Project (Upper Rhine Graben, Germany). - Quaternaire, 16/3: 191-199.

Ellwanger, D. (2003), unter Mitarbeit von Neeb, I. \& Lämmermann-Barthel, J.: Eine landschaftsübergreifende Lockergesteinsgliederung vom Alpenrand zum Oberrhein. - In: SCHIRMER, W. (ed.): Landschaftsgeschichte im europäischen Rheinland. - GeoArchaeoRhein, 4: 81-124.

ENGESSER, W. \& MüNZING, K. (1991): Molluskenfaunen aus Bohrungen im Raum PhilippsburgMannheim und ihre Bedeutung für die Quartärstratigraphie des Oberrheingrabens. - Jahresheft Geologisches Landesamt Baden-Württemberg, 33: 97-117.

Fezer, F. (1998): Mittel- und Jungpleistozän im „Heidelberger Loch“, Bohrprofil Entensee von $285 \mathrm{~m}$ bis $6 \mathrm{~m}$ Teufe. - Jahresbericht und Mitteilungen des Oberrheinischen Geologischen Vereines, Neue Folge, 80: 297-360.

FIEBIG, M. (1999): Zur geologischen Aufnahme von quartären Lockergesteinen. - Zeitschrift für geologische Wissenschaften, 27/1/2: 135-152.

Gabriel, G., Ellwanger, D., Hoselmann, C. \& Weidenfeller, M. (2008): The Heidelberg Basin Drilling Project. - Quaternary Science Journal (Eiszeitalter und Gegenwart), 57/3-4: 253-269.

Giamboni, M., Wetzel, A., Nivière, B. \& SchumACHER, M. (2004): Plio-Pleistocene folding in the southern Rhinegraben recorded by the evolution of the drainage network (Sundgau area; northwestern Switzerland and France). - Eclogae Geologicae Helvetiae, 97/1: 17-31.

Gideon, G.O., Lopes Cardozo, G. \& Behrmann, J.H. (2006): Kinematic analysis of the Upper Rhine Graben boundary fault system. - Journal of Structural Geology 28/6: 1028-1039.
Hagedorn, E.-M. (2004): Sedimentpetrographie und Lithofazies der Jungtertiären und Quartären Sedimente im Oberrheingebiet. - PhD thesis, Mathematisch-Naturwissenschaftliche Fakultät, Universität zu Köln: 248 p.

Hahne, J., Ellwanger, D. \& Stritzke, R. (2008): Evidence for a Waalian thermomer pollen record from the research borehole Heidelberg UniNord, Upper Rhine Graben, Baden-Württemberg. - Quaternary Science Journal (Eiszeitalter und Gegenwart), 57/3-4:403-410.

Haimberger, R., Hoppe, A. \& SchäFer, A. (2005): High-resolution seismic survey on the Rhine River in the northern Upper Rhine Graben. - International Journal of Earth Sciences / Geologische Rundschau, 94: 657-668.

Hoselmann, C. (1994): Stratigraphie des Hauptterrassenbereichs am unteren Mittelrhein. - Geologisches Institut der Universität zu Köln, Sonderveröffentlichungen, 96: $235 \mathrm{p}$.

Hoselmann, C. (2008): The Pliocene and Pleistocene fluvial evolution in the northern Upper Rhine Graben based on results of the research borehole at Viernheim (Hessen, Germany). - Quaternary Science Journal (Eiszeitalter und Gegenwart), 57/3-4: 286-315.

Hunze, S. \& Wonik, T. (2008): Sediment Input into the Heidelberg Basin as determined from Downhole Logs. - Quaternary Science Journal (Eiszeitalter und Gegenwart), 57/3-4: 367-381.

Hydrogeologische Kartierung Und GrundwasserBEWIRTSCHAFTUNG RHEIN-NECKAR-RAum (HGK), ForTSCHREIBUNG 1983-1998 (1999). - Ministerium für Umwelt und Verkehr Baden-Württemberg, Hessisches Ministerium für Umwelt, Landwirtschaft und Forsten, Ministerium für Umwelt und Forsten Rheinland-Pfalz: 1 - 155.

Kemna, H. (2008): A revised Stratigraphy for the Pliocene and Lower Pleistocene deposits of the lower Rhine embayment. - Netherlands Journal of Geosciences - Geologie en Mijnbouw, 87/1: 91-105.

Kemna, H. \& Westerhoff, W. (2007): Remarks on the palynology-based chronostratigraphical subdivision of pliocene terrestrial deposits in NW-Europe. - Quaternary International, 164165: 184-196.

KNIPPING, M. (2002): Pollenanalytische Untersuchungen am Profil ,Schifferstadt BK 30c GM'. - Arbeitsbericht Geologisches Landesamt Rheinland-Pfalz, Mainz: $11 \mathrm{p}$.

KnIPPING, M. (2008): Early and Middle Pleistocene pollen assemblages of deep core drillings in 
the northern Upper Rhine Graben, Germany. - Netherlands Journal of Geosciences - Geologie en Mijnbouw, 87/1: 51-65.

Löscher, M. (1996): Die Schotterablagerungen in der alten Neckarschleife von Mauer. - In: BeINhauer, K., KraAtz, R. \& Wagner, G.A. (eds.): Homo erectus heidelbergensis von Mauer: Kolloquium I, Neue Funde und Forschungen zur Frühen Menschheitsgeschichte Eurasiens mit einem Ausblick auf Afrika: 17-27.

MiALL, A.D. (1985): Architectural-element analyses: a new method of facies analyses applied to fluvial deposits. - Earth Science Reviews, 22: 261-308.

Miall, A.D. (1996): The Geology of Fluvial Deposits. Sedimentary Facies, Basin Analysis and Petroleum Geology. - 582 p.; Berlin(Springer).

OGG, J., OGG, G. \& Gradstein, F. (2008): The Concise Geologic Time Scale. - 184 p.; Cambridge et al. (Cambridge University Press).

Peters, G. (2007): Active tectonics in the Upper Rhine Graben - Integration of paleoseismology, geomorphology, and geomechanical modelling. - PhD thesis, Vrije Universiteit Amsterdam: $270 \mathrm{p}$.

Rolf, C., Hambach, U. \& Weidenfeller, M. (2008): Rock and palaeomagnetic evidence for the Plio/ Pleistocene palaeoclimatic change recorded in Upper Rhine Graben sediments (Bohrung Ludwigshafen-Parkinsel). - Netherlands Journal of Geosciences - Geologie en Mijnbouw, 87/1: 41-50.

Rotstein, Y., Edel, J.-B., Gabriel, G., Boulanger, D., Schaming, M. \& Munschy, M. (2006): Insight into the structure of the Upper Rhine Graben and its basement from a new compilation of Bouguer Gravity. - Tectonophysics, 425: 55-70.

SAlomon, W. (1927): Die Erbohrung der Heidelberger Radium-Sol-Therme und ihre geologischen Verhältnisse. - Abhandlungen Heidelberger Akademie der Wissenschaften, 14: 1- 105.

Schumacher, M.E. (2002): Upper Rhine Graben: Role of preexisting structures during rift evolution. - Tectonics, 21/1: doi:10.1029/ 2001 TC900022.

Simon, T. (2008): Die Bohrung Frankenbach. - Naturf. Hefte 14, Naturkundemuseum Heilbronn /Neckar.

Symbolschlüssel Geologie Baden-Württemberg (2007): Verzeichnis Geologischer Einheiten - Aktualisierte Ausgabe März 2007. - InternetPubl.: http://www.lgrb.uni-freiburg.de; Freiburg i. Br. (Reg.-Präs. Freiburg - L.-Amt Geol. Rohst. Bergb.).

VANDENBERghe, J. (1993): Changing fluvial processes under changing periglacial conditions. - Zeitschrift für Geomorphologie N. F., Suppl., 88: $17-28$.

VAndenberghe, J. (1995): Time scales, climate and river development. - Quaternary Science Reviews, 14: 631-638.

VILLINGER, E. (1998): Zur Flußgeschichte von Rhein und Donau in Südwestdeutschland. - Jahresberichte und Mitteilungen des Oberrheinischen Geologischen Vereines, Neue Folge 80: 361 -398 .

Weidenfeller, M. \& Kärcher, T. (2008): Tectonic influence on fluvial preservation: Aspects of the architecture of Middle and Late Pleistocene sediments in the northern Upper Rhine Graben, Germany. - Netherlands Journal of Geosciences - Geologie en Mijnbouw, 87/1: 33-40.

Weidenfeller, M. \& Knipping, M. (2008): Correlation of Pleistocene sediments from boreholes in the Ludwigshafen area, western Heidelberg Basin. - Quaternary Science Journal (Eiszeitalter und Gegenwart), 57/3-4: 270-285.

Westerhoff, W. (2004): Upper Pliocene and lower Pleistocene Rhine-Meuse deposits in the Tegelen-Reuver type area. - In: Kemna, H. (ed.): DEUQUA-meeting 2004, Nijmegen Excursion guide: $79-130$.

Westerhoff, W. (2008): Stratigraphy and sedimentary evolution. The lower Rhine Meuse system during the Late Pliocene and Early Pleistocene (southern North Sea Basin). - PhD thesis Vrije Universiteit Amsterdam. Geology of the Netherlands 1: 1-168.

Wirsing, G., Luz, A., Engesser, W. \& Koch, A. (2007,) unter Mitarbeit von Elsass, P. \& Perrin, J.: Hochauflösende Reflexionsseismik auf dem Rhein und dem Rheinseitenkanal zwischen Mannheim und Rheinfelden. - Fachbericht 1/07, Regierungspräsidium Freiburg, Landesamt für Geologie, Rohstoffe und Bergbau: $60 \mathrm{p}$.

ZaGwisn, W.H. (1963): Pleistocene stratigraphy in the Netherlands, based on changes in vegetation and climate. - Verhand. van het konink. Nederl. Geol. Mijnb. Gen. Geol. Serie, 21-2: 173-197

ZiegLer, P. (1992): European Cenozoic rift system. In: Ziegler, P.A. (Ed.): Geodynamics of Rifting, Volume I. Case History Studies on Rifts: Europe and Asia. - Tectonophysics, 208: 91-111. 